\title{
Recent Development of Islamic Corporate Social Responsibility
}

\author{
Rini Setyaningsih ${ }^{1 *}$, Doddy Setiawan ${ }^{2}$ \\ *Corresponding author
}

\begin{abstract}
This study aims to review the development of research related to Islamic corporate social responsibility in well-known international journals such as the past ten years. The research review based on 42 articles. The 40 articles in international journals, and two articles in nationally accredited journals from 2009 until 2018. The analysis technique used in this study is charting the field method. This study classifies sample articles based on topics, variables, and research methods. The results of the review indicate that the majority of researchers discuss topics other than antecedents, and the consequences are 29 articles, of which 7 of them specifically discuss the measurement of Islamic corporate social responsibility. The antecedent variable dominated by company size and SSB size that calculates for each of 3 articles and the most discussed consequence variable is the financial performance of 3 articles, while the most dominant method used by researchers is an analytical method that counts 18 articles.
\end{abstract}

Keywords: corporate social responsibility, Islamic bank, Islamic financial institution

JEL Classification: G21, M41

\begin{abstract}
Abstrak. Penelitian ini bertujuan untuk meninjau perkembangan penelitian terkait tanggung jawab sosial perusahaan islam di jurnal internasional ternama dalam periode 10 tahun terakbir. Tinjauan penelitian didasarkan pada 42 artike yakni 40 artikel di jurnal terakreditasi internasional dan 2 artikel di jurnal terakreditasi nasional dengan periode observasi 20092018. Teknik analisis yang digunakan dalam penelitian ini adalah charting the field method. Penelitian ini mengklasifikasikan artikel sampel berdasarkan topik, variabel, dan metode penelitian. Hasil tinjauan menunjukkan bahwa mayoritas peneliti membahas topik selain anteseden dan konsekuensinya terhitung ada 29 artikel, yang mana 7 diantaranya secara khusus membahas tentang pengukuran tanggung jawab sosial perusahaan islam. Variabel anteseden didominasi oleh ukuran perusahaan dan ukuran SSB yang terhitung untuk masingmasing sebanyak 3 artikel dan variabel konsekuensi yang paling banyak dibahas adalah kinerja keuangan sebanyak 3 artikel. Sedangkan metode yang paling dominan digunakan oleh peneliti adalah metode analitikal yang terhitung ada 18 artikel.
\end{abstract}

Kata Kunci: tanggung jawab sosial perusahaan, bank syariah, lembaga keuangan syariah

\section{How to Cite:}

Setyaningsih, R., \& Setiawan, D. (2019). Recent Development of Islamic Corporate Social Responsibility. Etikonomi: Jurnal Ekonomi. Vol. 18 (2): 287 - 302. doi: http//dx.doi.org/10.15408/etk.v18i2.10807. 


\section{Introduction}

At present, the business world no longer focuses on financial statements (single bottom line) but must also pay attention to the three main aspects, namely the financial, environmental, and social aspects (triple bottom line). In recent years, businesses have begun to realize that the survival of a company cannot depend solely on the efficient use of resources to maximize short-term profits. However, the company is also required to engage in corporate social responsibility activities as a step to get involved in improving social quality, economy, culture, and society. Corporate social responsibility is important because there is still a lack of awareness of both the community and business people on social and environmental issues.

Corporate social responsibility has become one of the points of interest of shareholders and stakeholders for the company. From year to year, the company contributes to practice. Corporate social responsibility and disclosures in annual reports are increasing, including sharia-based companies. This fact has led many researchers to be interested in conducting more in-depth research related to corporate social responsibility in sharia-based companies known as Islamic corporate social responsibility.

Research on Islamic corporate social responsibility has been carried out both in Indonesia, for example, Sunarsih \& Nurhikmah (2017), and Wulandari (2016). Also, the researches from abroad, as by Platonova et al., (2018), Mallin et al., (2014), Kamla \& G. Rammal (2013), Zaki et al., (2014), Ullah et al. (2014) and Di Bella \& Al-Fayoumi (2016). From various studies, the results obtained are very varied and exciting to reexamine. Both from the antecedents and the consequences of the practices and disclosures of Islamic corporate social responsibility, from the development of accounting and business management journals in Indonesia and abroad that try to document and evaluate the results of these studies has motivated researchers to further examine how the development of research regarding the practice and disclosure of Islamic corporate social responsibility in bibliographic forms.

This research motivates by research conducted by Hesford et al. (2007) regarding bibliographic research in management accounting. The researcher tries to examine the practice and disclosure of Islamic corporate social responsibility in the world with the same method by using the results of research from 42 articles on Islamic corporate social responsibility in 26 internationally accredited journals and one nationally accredited journal for ten years (from 2009 until by 2018). Researchers choose accredited journals as observation material because accredited journals have gone through rigorous selection so that the articles published have good credibility and quality. This study uses two approaches, namely "charting the field" and "analyzing the community" to analyze and map the development of research on Islamic corporate social responsibility over the past ten years from several accredited journals.

This study provides at least three contributions to the accounting literature. First, provide historical evidence of the development of ICSR research for ten years in international accreditation journals, so that it can be a material for literature review for further research that will examine the subject of Islamic social responsibility. Second, this article provides evidence that throughout 2009-2018, ICSR was still an exciting topic to study. Third, this 
study provides knowledge of the most frequently researched issues and the least frequently investigated in ICSR, as well as the dominant research methods used by previous researchers.

\section{Methods}

This study applies a research method that has been developed by Hesford et al. (2006), namely the method of "Charting The Field." In the literature review approach, this study also refers to research on bibliography conducted by Dewi et al. (2018). The criteria for selecting research journals include the following: first, journals include accredited international and national journals. Second, journals can be accessed online. Third, researchers only choose articles related to Islamic corporate social responsibility.

Table 1. List of Journal

\begin{tabular}{|c|c|c|}
\hline Name of Journals & Institutions & Articles \\
\hline Accounting, Auditing \& Accountability Journal & Emerald & 1 \\
\hline Accounting Research Journal & Emerald & 1 \\
\hline Asian Journal Business Ethics & Springer & 1 \\
\hline Business Ethics: A European Review & Wiley & 1 \\
\hline Competitiveness Review & Emerald & 1 \\
\hline EuroMed Journal of Business & Emerald & 1 \\
\hline Humanomics & Emerald & 2 \\
\hline International Journal of Bank Marketing & Emerald & 2 \\
\hline Int. Journal of Islamic and Middle Eastern Finance and Management & Emerald & 4 \\
\hline International Journal of Social Economics & Emerald & 1 \\
\hline ISRA International Journal of Islamic Finance & Emerald & 1 \\
\hline Journal Finance Service Research & Springer & 1 \\
\hline Journal Business Ethics & Springer & 6 \\
\hline Journal of Economic Behavior \& Organization & Elsevier & 1 \\
\hline Journal of Family Business Management & Emerald & 1 \\
\hline Journal of Financial Reporting and Accounting & Emerald & 2 \\
\hline Journal of Islamic Accounting and Business Research & Emerald & 1 \\
\hline Journal of Islamic Marketing & Emerald & 2 \\
\hline Journal of Management Development & Emerald & 1 \\
\hline Management of Environmental Quality: An International Journal & Emerald & 1 \\
\hline Management Research Review & Emerald & 1 \\
\hline Management Review Quarterly & Springer & 1 \\
\hline Managerial Auditing Journal & Emerald & 1 \\
\hline Renewable and Sustainable Energy Reviews & Elsevier & 1 \\
\hline Research in International Business and Finance & Elsevier & 2 \\
\hline Social Responsibility Journal & Emerald & 2 \\
\hline Etikonomi & UIN Jakarta & 2 \\
\hline Total & & 42 \\
\hline
\end{tabular}


The researcher chose sample articles systematically with the following steps: first, researchers focused on internationally accredited journals such as Emerald-insight, Springer, Elsevier, and Wiley. The researcher also sampled articles from one of the national accredited journals, namely Etikonomi. The researcher selects articles from the Etikonomi Journal as a case study from an accredited national journal. Second, the researcher enters the website of the journal mentioned. Third, researchers include keywords such as accounting, economics, business, and management. Fourth, after entering specialized accounting economics journals, researchers include keywords such as Islamic CSR and CSR in Islamic banks. Fifth, researchers only limit articles in the 2009-2018-publication period. Sixth, download articles that are relevant to the research topic. Seventh, researchers classify sample articles based on topics, variables, and research methods used.

\section{Result and Discussion}

This study uses 42 articles obtained from 26 internationally accredited journals and one national accredited journal that meet the sample criteria. The name of the journal, the articles' title, and the researchers' names present in Table 2.

Table 2. List of Article

\begin{tabular}{|c|c|c|c|}
\hline No & Name of Journal & Title & Author \\
\hline 1 & $\begin{array}{l}\text { Accounting Research } \\
\text { Journal }\end{array}$ & $\begin{array}{l}\text { Integrating the social maslaha into Islamic } \\
\text { finance }\end{array}$ & (Cebeci, 2012) \\
\hline 2 & $\begin{array}{l}\text { Accounting, Auditing \& } \\
\text { Accountability J. }\end{array}$ & $\begin{array}{l}\text { Social reporting by Islamic banks: does social } \\
\text { justice matter? }\end{array}$ & (Kamla \& Rammal, 2013) \\
\hline 3 & Asian Journal Buss. Ethics & $\begin{array}{l}\text { The association of Islamic bank ethical } \\
\text { identity and financial performance: evidence } \\
\text { from Asia }\end{array}$ & (Zaki et al., 2014) \\
\hline 4 & $\begin{array}{l}\text { Business Ethics: A European } \\
\text { Review }\end{array}$ & $\begin{array}{l}\text { Socially responsible investment: insights from } \\
\text { Shari'a departments in Islamic financial } \\
\text { institutions }\end{array}$ & (Ullah et al., 2014) \\
\hline 5 & Competitiveness Review & $\begin{array}{l}\text { Developing an Islamic corporate social } \\
\text { responsibility model (ICSR) }\end{array}$ & (Khurshid et al., 2014) \\
\hline 6 & $\begin{array}{l}\text { EuroMed Journal of } \\
\text { Business }\end{array}$ & $\begin{array}{l}\text { Perception of Stakeholders on Corporate Social } \\
\text { Responsibility of Islamic Banks in Jordan }\end{array}$ & $\begin{array}{l}\text { (Di Bella \& Al-Fayoumi, } \\
\text { 2016) }\end{array}$ \\
\hline 7 & Humanomics & $\begin{array}{l}\text { Corporate social responsibility of Islamic } \\
\text { financial institutions and businesses: } \\
\text { Optimizing charity value }\end{array}$ & (Hassan \& Latiff, 2009) \\
\hline 8 & Humanomics & $\begin{array}{l}\text { Corporate social responsibility disclosure } \\
\text { index of Malaysian Shariah - compliant } \\
\text { companies }\end{array}$ & (Said et al., 2018) \\
\hline 9 & $\begin{array}{l}\text { Int.Journal of Bank } \\
\text { Marketing }\end{array}$ & $\begin{array}{l}\text { Are Malaysian Islamic banks' corporate social } \\
\text { responsibilities effective? A stakeholders' } \\
\text { view }\end{array}$ & (Jaiyeoba et al., 2018) \\
\hline 10 & $\begin{array}{l}\text { Int. Journal of Bank } \\
\text { Marketing }\end{array}$ & $\begin{array}{l}\text { Exploring the mechanism of consumer } \\
\text { responses to CSR activities of Islamic banks: } \\
\text { The mediating role of Islamic ethics fit }\end{array}$ & (Mostafa \& ElSahn, 2016) \\
\hline
\end{tabular}




\begin{tabular}{|c|c|c|c|}
\hline No & Name of Journal & Title & Author \\
\hline 11 & $\begin{array}{l}\text { Int. Journal of Islamic and } \\
\text { Middle Eastern Finance and } \\
\text { Management }\end{array}$ & $\begin{array}{l}\text { Exploring corporate social responsibility } \\
\text { disclosure: the case of Islamic banks }\end{array}$ & $\begin{array}{l}\text { (Hassan \& Harahap, } \\
\text { 2010) }\end{array}$ \\
\hline 12 & $\begin{array}{l}\text { Int. Journal of Islamic and } \\
\text { Middle Eastern Finance and } \\
\text { Management }\end{array}$ & $\begin{array}{l}\text { Evaluating the corporate social performance } \\
\text { of Islamic financial institutions: an empirical } \\
\text { study }\end{array}$ & (Sairally, 2013) \\
\hline 13 & $\begin{array}{l}\text { Int. Journal of Islamic and } \\
\text { Middle Eastern Finance and } \\
\text { Management }\end{array}$ & $\begin{array}{l}\text { Determinants of compliance with AAOIFI } \\
\text { standards by Islamic banks }\end{array}$ & $\begin{array}{l}\text { (El-Halaby \& Hussainey, } \\
\text { 2016) }\end{array}$ \\
\hline 14 & $\begin{array}{l}\text { Int. Journal of Islamic and } \\
\text { Middle Eastern Finance \& } \\
\text { Management }\end{array}$ & $\begin{array}{l}\text { How socially responsible investing can } \\
\text { help bridge the gap between Islamic and } \\
\text { conventional } \\
\text { Financial markets }\end{array}$ & (Bennett \& lqbal, 2013) \\
\hline 15 & $\begin{array}{l}\text { Int. Journal of Social } \\
\text { Economics }\end{array}$ & $\begin{array}{l}\text { Young Saudi consumers and corporate social } \\
\text { responsibility: an Islamic "CSR tree" model }\end{array}$ & (Alfakhri et al., 2018b) \\
\hline 16 & $\begin{array}{l}\text { ISRA Int. Journal of Islamic } \\
\text { Finance }\end{array}$ & $\begin{array}{l}\text { CSR practices of Palestinian Islamic } \\
\text { banks: contribution to socio-economic } \\
\text { development }\end{array}$ & (Migdad, 2017) \\
\hline 17 & $\begin{array}{l}\text { Journal Finance Service } \\
\text { Research }\end{array}$ & $\begin{array}{l}\text { Corporate Social Responsibility, Shariah- } \\
\text { Compliance, and Earnings Quality }\end{array}$ & (Alsaadi et al., 2017) \\
\hline 18 & Journal Business Ethics & $\begin{array}{l}\text { Ethical Reporting in Islami Bank Bangladesh } \\
\text { Limited (1983-2010) }\end{array}$ & (Belal et al., 2015) \\
\hline 19 & Journal Business Ethics & $\begin{array}{l}\text { Corporate Social Responsibility and Islamic } \\
\text { Financial Institutions (IFIs): Management } \\
\text { Perceptions from IFIs in Bahrain }\end{array}$ & (Aribi \& Arun, 2015) \\
\hline 20 & Journal Business Ethics & $\begin{array}{l}\text { Islam and CSR: A Study of the Compatibility } \\
\text { Between the Tenets of Islam and the UN } \\
\text { Global Compact }\end{array}$ & (Williams \& Zinkin, 2010) \\
\hline 21 & Journal Business Ethics & $\begin{array}{l}\text { The Impact of Corporate Social Responsibility } \\
\text { Disclosure on Financial Performance: } \\
\text { Evidence from the GCC Islamic Banking } \\
\text { Sector }\end{array}$ & (Platonova et al., 2018) \\
\hline 22 & Journal Business Ethics & $\begin{array}{l}\text { Conceptualization of CSR Among Muslim } \\
\text { Consumers in Dubai: Evolving from } \\
\text { Philanthropy to Ethical and Economic } \\
\text { Orientations }\end{array}$ & $\begin{array}{l}\text { (Goby \& Nickerson, } \\
\text { 2016) }\end{array}$ \\
\hline 23 & Journal Business Ethics & $\begin{array}{l}\text { Exploring Muslim Attitudes Towards } \\
\text { Corporate Social Responsibility: Are Saudi } \\
\text { Business Students Different? }\end{array}$ & (Murphy et al., 2019) \\
\hline 24 & $\begin{array}{l}\text { Journal of Ec. Behavior \& } \\
\text { Org. }\end{array}$ & $\begin{array}{l}\text { Corporate Social Responsibility and Financial } \\
\text { Performance in Islamic Banks }\end{array}$ & (Mallin et al., 2014) \\
\hline 25 & $\begin{array}{l}\text { Journal of Family Business } \\
\text { Management }\end{array}$ & $\begin{array}{l}\text { Virtuous CSR: an Islamic family business in } \\
\text { Malaysia }\end{array}$ & (Yusof et al., 2014) \\
\hline 26 & $\begin{array}{l}\text { Journal of Financial } \\
\text { Reporting and Accounting }\end{array}$ & $\begin{array}{l}\text { Corporate social responsibility disclosure: } \\
\text { A comparison between Islamic and } \\
\text { conventional financial institutions }\end{array}$ & (Aribi \& Gao, 2010) \\
\hline 27 & $\begin{array}{l}\text { Journal of Financial } \\
\text { Reporting and Accounting }\end{array}$ & $\begin{array}{l}\text { Social responsibility disclosure in Islamic } \\
\text { banks: a comparative study of Indonesia and } \\
\text { Malaysia }\end{array}$ & (Amran et al., 2017) \\
\hline
\end{tabular}


Rini Setyaningsih. Recent Development of Islamic Corporate

\begin{tabular}{|c|c|c|c|}
\hline No & Name of Journal & Title & Author \\
\hline 28 & $\begin{array}{l}\text { Journal of Islamic } \\
\text { Accounting and } \\
\text { Business Research }\end{array}$ & $\begin{array}{l}\text { Determinants of corporate social } \\
\text { responsibility disclosure: the case of Islamic } \\
\text { banks }\end{array}$ & (Farook et al., 2011) \\
\hline 29 & $\begin{array}{l}\text { Journal of Islamic } \\
\text { Marketing }\end{array}$ & $\begin{array}{l}\text { A citation analysis of corporate social } \\
\text { responsibility (1970-2014): insights from } \\
\text { Islamic perspective }\end{array}$ & (Alfakhri et al., 2018a) \\
\hline 30 & $\begin{array}{l}\text { Journal of Islamic } \\
\text { Marketing }\end{array}$ & $\begin{array}{l}\text { On corporate social responsibility and Islamic } \\
\text { marketing }\end{array}$ & (Koku et al., 2014) \\
\hline 31 & $\begin{array}{l}\text { Journal of Management } \\
\text { Dev't }\end{array}$ & $\begin{array}{l}\text { Toward applied Islamic business ethics: } \\
\text { responsible halal business }\end{array}$ & (Ismaeel \& Blaim, 2012) \\
\hline 32 & $\begin{array}{l}\text { Management of } \\
\text { Environmental } \\
\text { Quality: An Int. Journal }\end{array}$ & $\begin{array}{l}\text { An analysis of Islamic CSR concept and the } \\
\text { opinions of Malaysian managers }\end{array}$ & (Siwar \& Hossain, 2009) \\
\hline 33 & $\begin{array}{l}\text { Management Research } \\
\text { Review }\end{array}$ & $\begin{array}{l}\text { Customer-centric corporate social responsibility } \\
\text { A framework for Islamic banks on ethical } \\
\text { efficiency }\end{array}$ & (Rashid et al., 2013) \\
\hline 34 & $\begin{array}{l}\text { Management Review } \\
\text { Quarterly }\end{array}$ & $\begin{array}{l}\text { Corporate social responsibility and Islamic } \\
\text { banks: a systematic literature review }\end{array}$ & (Zafar \& Sulaiman, 2019) \\
\hline 35 & $\begin{array}{l}\text { Managerial Auditing } \\
\text { Journal }\end{array}$ & $\begin{array}{l}\text { Narrative disclosure of corporate } \\
\text { social responsibility in Islamic financial } \\
\text { institutions }\end{array}$ & (Aribi \& Gao, 2011) \\
\hline 36 & $\begin{array}{l}\text { Renewable and Sustainable } \\
\text { Energy Reviews }\end{array}$ & $\begin{array}{l}\text { Corporate sustainability disclosure in annual } \\
\text { reports: Evidence from UAE banks : Islamic } \\
\text { versus conventional }\end{array}$ & (Nobanee \& Ellili, 2016) \\
\hline 37 & $\begin{array}{l}\text { Research in Int. Business } \\
\text { and Finance }\end{array}$ & $\begin{array}{l}\text { Empowering social responsibility of Islamic } \\
\text { organizations through Waqf }\end{array}$ & (Darus et al., 2017) \\
\hline 38 & $\begin{array}{l}\text { Research in Int. Business } \\
\text { and Finance }\end{array}$ & $\begin{array}{l}\text { Corporate governance and operational risk } \\
\text { voluntary disclosure: evidence from Islamic } \\
\text { banks }\end{array}$ & (Neifar \& Jarboui, 2018) \\
\hline 39 & $\begin{array}{l}\text { Social Responsibility } \\
\text { Journal }\end{array}$ & $\begin{array}{l}\text { An introspect into the Islamic roots of CSR in } \\
\text { the Middle East: the case of Savola Group in } \\
\text { Egypt }\end{array}$ & $\begin{array}{l}\text { (Darrag \& E-Bassiouny, } \\
\text { 2013) }\end{array}$ \\
\hline 40 & $\begin{array}{l}\text { Social Responsibility } \\
\text { Journal }\end{array}$ & $\begin{array}{l}\text { Religiosity and Corporate Social } \\
\text { Responsibility Practices: Evidence from an } \\
\text { Emerging Economy }\end{array}$ & (Zaman et al., 2018) \\
\hline 41 & Etikonomi & $\begin{array}{l}\text { Determinant of The Corporate Social } \\
\text { Responsibility Disclosure }\end{array}$ & $\begin{array}{l}\text { (Sunarsih \& Nurhikmah, } \\
\text { 2017) }\end{array}$ \\
\hline 42 & Etikonomi & $\begin{array}{l}\text { The Impact of Corporate Social Responsibility } \\
\text { on Accrual Earnings Management and Real } \\
\text { Earning Management }\end{array}$ & (Wulandari, 2016) \\
\hline
\end{tabular}

Figure 1 shows the trends of Islamic Corporate Social Responsibility research. The researcher chose ten years between 2009 and 2018 because, in this period, research on Islamic corporate social responsibility began to increase and experienced an increase from year to year even though it had declined in 2015 and 2017. The selection process resulted in 42 articles. The researcher chose the period 2009 to 2018 with consideration to further review the research on ICSR, in which the accreditation journal that provided 
the ICSR research room in 2009 was two articles published in the journal Management of Environmental Quality: An International Journal and Humanomics. Whereas in 2018, there were seven articles published in the journal Humanomics, International Journal of Bank Marketing, International Journal of Social Economics, Journal of Business Ethics, Journal of Islamic Marketing, Management Review Quarterly, and Social Responsibility Journal. This study classifies the bibliographic data of the article consisting of the journals' name, the publications' year, the articles' title, and the researchers' name. Articles that are not available online do not include researchers in journal selection.

Figure 1. Trends of ICSR research throughout 2009-2018

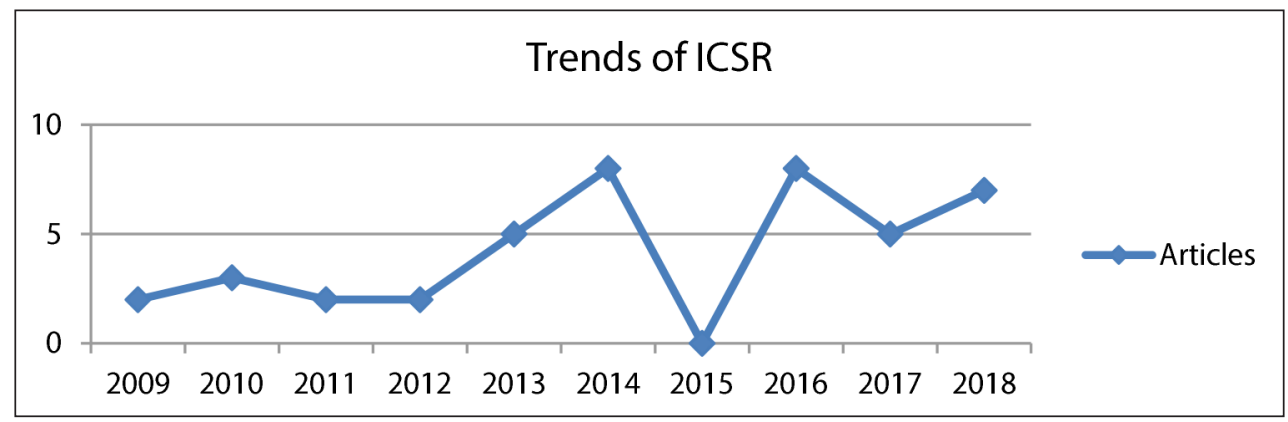

Table 3 shows the sample used in this study according to the observation period. There is one journal that dominates research regarding Islamic corporate social responsibility, namely Journal Business Ethics for 14.28\%. While, Journal of Islamic and Middle Eastern Finance and Management 9.52\%, Humanomics, International Journal of Bank Marketing, Journal of Financial Reporting and Accounting, Journal of Islamic Marketing, Research in International Business and Finance, and Social Responsibility Journal and Ethics, respectively at 4.67\%, as well as Accounting, Auditing \& Accountability Journal, Accounting Research Journal, Asian Journal of Business Ethics, Business Ethics: A European Review, Competitiveness Review, EuroMed Journal of Business, International Journal of Social Economics, ISRA International Journal of Islamic Finance, Journal of Finance Research Services, Journal of Economic Behavior \& Organization, Journal of Family Business Management, Journal of Islamic Accounting and Business Research, Journal of Management Development, Management of Environmental Quality: An International Journal , Management Research Review, Quarterly Management Review, Managerial Auditing Journal, and Renewable and Sustainable Energy Reviews, each at $2.38 \%$.

Based on Table 3, the average comparison of two periods, namely period 1 between 2009 up to 2013 and period 2 between 2014 and 2018 also showed that there was an increase in the number of articles regarding Islamic corporate social responsibility in the last decade, from 14 articles to 28 articles or about 50\% increase. The increase was influenced by a significant increase in the number of studies in several journals such as International Journal of Bank Marketing, Journal of Business Ethics, Journal of Islamic Marketing, Research in International Business and Finance and Ethics. 
Rini Setyaningsih. Recent Development of Islamic Corporate

Table 3. Sample Description

\begin{tabular}{|c|c|c|c|c|c|c|}
\hline \multirow{2}{*}{ Name of Journal } & \multicolumn{2}{|c|}{ 2009-2018 } & \multicolumn{2}{|c|}{ 2009-2013 } & \multicolumn{2}{|c|}{ 2014-2018 } \\
\hline & Number & Percentage & Number & Percentage & Number & Percentage \\
\hline $\begin{array}{l}\text { Accounting, Auditing \& } \\
\text { Accountability Journal }\end{array}$ & 1 & 2.38 & 1 & 7.14 & 0 & 0.00 \\
\hline Accounting Research Journal & 1 & 2.38 & 1 & 7.14 & 0 & 0.00 \\
\hline Asian Journal Business Ethics & 1 & 2.38 & 0 & 0.00 & 1 & 3.57 \\
\hline $\begin{array}{l}\text { Business Ethics: A European } \\
\text { Review }\end{array}$ & 1 & 2.38 & 0 & 0.00 & 1 & 3.57 \\
\hline Competitiveness Review & 1 & 2.38 & 0 & 0.00 & 1 & 3.57 \\
\hline EuroMed Journal of Business & 1 & 2.38 & 0 & 0.00 & 1 & 3.57 \\
\hline Humanomics & 2 & 4.76 & 1 & 7.14 & 1 & 3.57 \\
\hline Int. Journal of Bank Marketing & 2 & 4.76 & 0 & 0.00 & 2 & 7.14 \\
\hline $\begin{array}{l}\text { Int. Journal of Islamic and } \\
\text { Middle Eastern Finance and } \\
\text { Management }\end{array}$ & 4 & 9.52 & 3 & 21.42 & 1 & 3.57 \\
\hline Int. Journal of Social Economics & 1 & 2.38 & 0 & 0.00 & 1 & 3.57 \\
\hline $\begin{array}{l}\text { ISRA Int. Journal of Islamic } \\
\text { Finance }\end{array}$ & 1 & 2.38 & 0 & 0.00 & 1 & 3.57 \\
\hline $\begin{array}{l}\text { Journal Finance Service } \\
\text { Research }\end{array}$ & 1 & 2.38 & 0 & 0.00 & 1 & 3.57 \\
\hline Journal Business Ethics & 6 & 14.28 & 1 & 7.14 & 5 & 17.85 \\
\hline $\begin{array}{l}\text { Journal of Economic Behavior } \\
\text { \& Organization }\end{array}$ & 1 & 2.5 & 0 & 0.00 & 1 & 3.57 \\
\hline $\begin{array}{l}\text { Journal of Family Business } \\
\text { Management }\end{array}$ & 1 & 2.5 & 0 & 0.00 & 1 & 3.57 \\
\hline $\begin{array}{l}\text { Journal of Financial Reporting } \\
\text { and Accounting }\end{array}$ & 2 & 4.76 & 1 & 7.14 & 1 & 3.57 \\
\hline $\begin{array}{l}\text { Journal of Islamic Accounting } \\
\text { and Business Research }\end{array}$ & 1 & 2.38 & 1 & 7.14 & 0 & 0.0 \\
\hline Journal of Islamic Marketing & 2 & 4.76 & 0 & 0.00 & 2 & 7.14 \\
\hline $\begin{array}{l}\text { Journal of Management } \\
\text { Development }\end{array}$ & 1 & 2.38 & 1 & 7.14 & 0 & 0.00 \\
\hline $\begin{array}{l}\text { Management of } \\
\text { Environmental Quality: An } \\
\text { Int. Journal }\end{array}$ & 1 & 2.38 & 1 & 7.14 & 0 & 0.00 \\
\hline Management Research Review & 1 & 2.38 & 1 & 7.14 & 0 & 0.00 \\
\hline Management Review Quarterly & 1 & 2.38 & 0 & 0.00 & 1 & 3.57 \\
\hline Managerial Auditing Journal & 1 & 2.38 & 1 & 7.14 & 0 & 0.00 \\
\hline $\begin{array}{l}\text { Renewable and Sustainable } \\
\text { Energy Reviews }\end{array}$ & 1 & 2.38 & 0 & 0.00 & 1 & 3.57 \\
\hline $\begin{array}{l}\text { Research in Int. Business and } \\
\text { Finance }\end{array}$ & 2 & 4.76 & 0 & 0.00 & 2 & 7.14 \\
\hline Social Responsibility Journal & 2 & 4.76 & 1 & 7.14 & 1 & 3.57 \\
\hline Etikonomi & 2 & 4.76 & 0 & 0.00 & 2 & 7.14 \\
\hline Total & 42 & & 14 & & 28 & \\
\hline
\end{tabular}


In this article, the researcher classifies each article in two groups, namely the topic and research method. The classification of articles on Islamic corporate social responsibility based on research topics divides into two, namely antecedents (factors that motivated Islamic Corporate Social Responsibility), consequences (the affect of Islamic Corporate Social Responsibility), combination, and others.

Table 4. Classification on Research Topic

\begin{tabular}{lcccccc}
\hline \multirow{2}{*}{$\begin{array}{c}\text { Research } \\
\text { Topics }\end{array}$} & Number & Percentage & Number & Percentage & Number & Percentage \\
\hline Antecedents & 4 & 9.52 & 1 & 7.14 & 3 & 10.71 \\
$\begin{array}{l}\text { Consequences } \\
\text { Antecedents \& }\end{array}$ & 8 & 19.04 & 1 & 7.14 & 7 & 25.00 \\
$\begin{array}{l}\text { Consequences } \\
\text { Others }\end{array}$ & 1 & 2.38 & 0 & 0.00 & 1 & 3.57 \\
\hline \multicolumn{1}{c}{ Total } & 29 & 69.04 & 12 & 85.71 & 17 & 60.71 \\
\hline
\end{tabular}

Table 4 shows the classification of articles about Islamic corporate social responsibility based on the topics discussed, as explained before, that the topics discussed classify into four. Table 4 concludes that during the last ten years, the most discussed topics were the antecedents and consequences of Islamic corporate social responsibility $(69.04 \%$ or 29 articles). While those discussing the consequences (the impact on Islamic corporate social responsibility) were around 19.04\% (8 articles), antecedents' topics (determinants of Islamic corporate social responsibility), which are around $9.52 \%$ ( 4 articles), and topics that combine antecedents and consequences are around $2.38 \%$ or just 1 article.

When compared between period 1 and period 2 there has been a significant increase in the antecedent topic from 1 article to 3 articles, the topic of consequences from 1 article to 7 , the topic of the combination of antecedents and the consequences of none being there namely 1 temporary article topic besides antecedents and consequences from 12 articles to 17 articles.

Table 5 explains in more detail what antecedent variables discussed by the researcher. Overall, out of the four articles that discuss antecedent variables, the variable size of the company, and the most dominant size of the sharia supervisory board are discussed with each variable, there are three articles. While the SSB Cross-membership variable, Reputable SSB, and Board Independence each have two articles and other variables, namely 1 article, it can conclude that the researchers examined more of the size factor of the company, the size of the sharia supervisory board that influenced the Islamic corporate social responsibility. 
Rini Setyaningsih. Recent Development of Islamic Corporate

Table 5. Classification on Antecedent Variables

\begin{tabular}{|c|c|c|c|c|}
\hline Antecedent Variables & Articles & + & - & No Effect \\
\hline \multicolumn{5}{|l|}{ ICSR } \\
\hline Auditor & 1 & - & - & 1 \\
\hline Firm Age & 2 & 2 & - & - \\
\hline Firm Size & 3 & 3 & - & - \\
\hline Profitability & 1 & - & - & 1 \\
\hline Sharia Auditing Department & 1 & 1 & - & - \\
\hline Number of Block Holders & 1 & - & - & 1 \\
\hline Institutional Ownership & 1 & - & - & 1 \\
\hline Foreign Ownership & 1 & - & - & 1 \\
\hline Existence of SSB & 1 & 1 & - & - \\
\hline SSB Size & 3 & 3 & - & - \\
\hline SSB Cross-membership & 2 & 2 & - & - \\
\hline SSB Reputable & 2 & 2 & - & - \\
\hline Doctoral qualification of SSB member & 1 & 1 & - & - \\
\hline Duality in Position & 1 & - & - & 1 \\
\hline Board Independence & 2 & 1 & - & 1 \\
\hline Uncertainty Avoidance & 1 & - & 1 & - \\
\hline Proportion of Muslim population & 1 & 1 & - & - \\
\hline Political Economy & 1 & - & 1 & - \\
\hline Investment Account Holders & 1 & 1 & - & - \\
\hline Financial Performance & 1 & 1 & - & - \\
\hline Board Size & 1 & - & - & 1 \\
\hline Ratio of Total Bank Finance & 1 & 1 & - & - \\
\hline GDP in Country & 1 & 1 & - & - \\
\hline Private & 1 & - & - & 1 \\
\hline Riba & 1 & 1 & - & - \\
\hline Zakat & 1 & - & - & 1 \\
\hline Mafsadah & 1 & 1 & - & - \\
\hline \multicolumn{5}{|l|}{ Non-ICSR } \\
\hline Institutional Ownership & 1 & 1 & - & - \\
\hline Profitability & 1 & - & - & 1 \\
\hline Board Independence & 1 & - & 1 & - \\
\hline Firm Size & 1 & - & - & 1 \\
\hline
\end{tabular}

As with the driving variable for non-ICSR disclosure, each of them has only 1 article. The variable is that institutional ownership has a positive effect on non-ICSR disclosures. Profitability and firm size do not influence non-ICSR disclosure, and lastly, board independence that has a negative impact on non-ICSR disclosures. 
Table 6. Classification on Consequence Variables

\begin{tabular}{lcccc}
\hline Consequence Variables & Articles & + & - & No Effect \\
\hline ICSR & 3 & 3 & - & - \\
Financial Performance & 1 & 1 & - & - \\
Charity Value & 1 & 1 & - & - \\
Earning Quality & 1 & 1 & - & - \\
Islamic Marketing & 1 & 1 & - & - \\
Socio-Economic Development & 1 & 1 & & - \\
Operational Risk & & & - & - \\
Non-ICSR & & & 1 & - \\
Earning Management & 1 & 1 & - & - \\
a. Accrual earning management & & & \\
b. Real earning management & & & \\
\hline
\end{tabular}

Table 6 shows the consequences or impact variables of Islamic corporate social responsibility discussed by the researcher. Of the eight articles that discuss Islamic corporate social responsibility, the most dominant impact discussed is the company's financial performance with three articles, while the impact on the value of charity, earnings quality, Islamic marketing, socio-economic development, and operational risk, each of which has only 1 article. In table 6 also presents the impact of non-ICS disclosures discussed by researchers, namely earnings management, which divides into two parts (accrual and real).

Table 7. Classification on Other Variables

\begin{tabular}{|c|c|c|}
\hline Other Variables & Number & Percentage (\%) \\
\hline Measuring ICSR & 7 & 24.13 \\
\hline Social Maslaha & 1 & 3.44 \\
\hline Social Justice & 1 & 3.44 \\
\hline Social Responsible Investment & 2 & 6.89 \\
\hline Narrative Disclosure & 1 & 3.44 \\
\hline Literature Review & 3 & 10.34 \\
\hline Halal Regulation \& Certification & 1 & 3.44 \\
\hline Waqf Fund & 1 & 3.44 \\
\hline Virtue Ethics & 1 & 3.44 \\
\hline Islamic Principle & 1 & 3.44 \\
\hline ICSR Model & 4 & 13.79 \\
\hline Management and consumer's Perception & 5 & 17.24 \\
\hline Muslim Attitude & 1 & 3.44 \\
\hline
\end{tabular}

Table 7 shows other topics discussed by the researcher. This other topic is researchers tried to analyze the practice of Islamic corporate social responsibility in conditions certain or constructing Islamic corporate social responsibility index measurements even researchers try 
to compare linking Islamic corporate social responsibility practices to several aspects of Islam such as sharia principles and endowments. The researchers are using Islamic corporate social responsibility variables as intervening and moderating variables. The 29 articles that discussed other topics from the most dominant discussion on Islamic corporate social responsibility, the ICSR index measurement was 7 articles, manager and consumer perceptions as many as 5 articles, ICSR model as many as 4 articles, literature reviews as many as 3 articles, social responsibility investments as much as 2 other articles and topics there are only 1 article.

The type of research method that is widely used by researchers to examine the practice of corporate social responsibility disclosure divides into three methods, namely the analytical method, the literature review method, and the survey method. Analytical methods include various data analysis techniques such as multiple regression, descriptive analysis, content analysis using various tools such as SPSS and E-Views to test relationships between variables. The literature review method is a comparison or case study of financial statements and retesting of indices and theories. The survey method is that researchers conduct questionnaires with a Likert scale to determine the perceptions of providers of financial statements and the parties concerned.

Table 8. Classification on Research Method

\begin{tabular}{|c|c|c|c|c|c|c|}
\hline \multirow{2}{*}{$\begin{array}{l}\text { Research } \\
\text { Method }\end{array}$} & \multicolumn{2}{|c|}{$2009-2018$} & \multicolumn{2}{|c|}{$2009-2013$} & \multicolumn{2}{|c|}{ 2014-2018 } \\
\hline & Number & Percentage & Number & Percentage & Number & Percentage \\
\hline Analytical & 18 & 42.85 & 7 & 50 & 11 & 39.28 \\
\hline Case Study & 2 & 4.76 & 0 & 0.00 & 2 & 7.14 \\
\hline Review & 8 & 19.04 & 4 & 28.57 & 4 & 14.28 \\
\hline Survey & 9 & 21.42 & 2 & 14.28 & 7 & 25 \\
\hline Combinations & 5 & 11.90 & 1 & 7.14 & 4 & 14.28 \\
\hline Total & 42 & & 14 & & 28 & \\
\hline
\end{tabular}

Based on Table 8, it can conclude that during the 10-year observation period (20092018), the most widely used research method was an analytical method, which accounted for 18 articles (42.85\%) - then followed by survey methods with 9 articles $(21.42 \%)$, review methods with 8 articles (19.04), combination methods as many as 5 articles (11.90) and the last one, using case studies only 2 articles (4.76\%). For the comparison between period 1 (2009-2013) and period 2 (2014-2018), the survey method, which experienced the most increase, was equal to 5 articles while the other method only increased slightly. In fact, for the review method did not experience an increase or decrease, it remained at four articles in 2 periods.

\section{Conclusion}

This review reflects the development of ICSR research for over ten years (20092018 period). Based on 42 articles in 40 articles from accredited international journals 
and two articles from the most researched accredited national journals that are related to ICSR measurement and analytical research methods are the dominant methods in ICSR research. The most discussed topics in ICSR articles are topics other than antecedents and consequences, namely 29 articles so that further research can examine further the topic of antecedents, topics of consequences, or topics on the combination of both.

Some implications of the results of this study include: first, there are still wide-open opportunities for research related to Islamic corporate social responsibility. For example, research on the consequences of ICSR on company value reflected in stock prices or testing ICSR determinants that have not been widely studied, such as the state Islamic index, given the importance of sharia principles in implementing ICSR activities. Second, it can provide an overview for the next researcher regarding findings based on topics, methods and scientific disciplines that have widely studied, as well as the characteristics of articles and journals in this study

This research is still limited to a period of 10 years. There are some limitations, including only analyzing articles with a span of 10 years (2009-2018), so that articles with the year of publication under 2009 were not analyzed. For further research, it is recommended to expand the research period. Besides, in this study, only samples were published in well-known journals such as Emerald-insight, Elsevier, Springer, and Wiley. It would be better, for the next researcher to add samples of published articles in other international journals in Scopus index.

\section{References}

Alfakhri, Y., Nurunnabi, M., \& Alfakhri, D. (2018a). A Citation Analysis of Corporate Social Responsibility (1970-2014): Insights from Islamic Perspective. Journal of Islamic Marketing, 9(3), 621-654. https://doi.org/10.1108/JIMA-09-2017-0092.

Alfakhri, Y., Nurunnabi, M., \& Alfakhri, D. (2018b). Young Saudi Consumers and Corporate Social Responsibility: an Islamic "CSR Tree" Model. International Journal of Social Economics, 45(12), 1570-1589. https://doi.org/10.1108/IJSE-09-2017-0395.

Alsaadi, A., Ebrahim, M. S., \& Jaafar, A. (2017). Corporate Social Responsibility, ShariahCompliance, and Earnings Quality. Journal of Financial Services Research, 51(2), 169194. https://doi.org/10.1007/s10693-016-0263-0.

Amran, A., Fauzi, H., Purwanto, Y., Darus, F., Yusoff, H., Zain, M. M., \& Nejati, M. (2017). Social Responsibility Disclosure in Islamic Banks: a Comparative Study of Indonesia and Malaysia. Journal of Financial Reporting and Accounting, 15(1), 99-115. https:// doi.org/10.1108/JFRA-01-2015-0016.

Aribi, Z. A., \& Arun, T. (2015). Corporate Social Responsibility and Islamic Financial Institutions (IFIs): Management Perceptions from IFIs in Bahrain. Journal of Business Ethics, 129(4), 785-794. https://doi.org/10.1007/s10551-014-2132-9.

Aribi, Z. A., \& Gao, S. (2010). Corporate Social Responsibility Disclosure. Journal of Financial Reporting and Accounting, 8(2), 72-91. https://doi.org/10.1108/19852511011088352. 
Aribi, Z. A., \& Gao, S. S. (2011). Narrative disclosure of corporate social responsibility in Islamic financial institutions. Managerial Auditing Journal, 27(2), 199-222.

Belal, A. R., Abdelsalam, O., \& Nizamee, S. S. (2015). Ethical Reporting in Islami Bank Bangladesh Limited (1983-2010). Journal of Business Ethics, 129(4), 769-784. https:// doi.org/10.1007/s10551-014-2133-8.

Bennett, M. S., \& Iqbal, Z. (2013). How Socially Responsible Investing Can Help Bridge the Gap between Islamic and Conventional Financial Markets. International Journal of Islamic and Middle Eastern Finance and Management, 6(3), 211-225. https://doi. org/10.1108/IMEFM-Aug-2012-0078.

Cebeci, I. (2012). Integrating the Social Maslaha into Islamic Finance. Accounting Research Journal, 25(3), 166-184. https://doi.org/10.1108/10309611211290158.

Darrag, M., \& E-Bassiouny, N. (2013). An introspect into the Islamic roots of CSR in the Middle East: the case of Savola Group in Egypt. Social Responsibility Journal, 9(3), 362-378. https://doi.org/10.1108/SRJ-10-2011-0096.

Darus, F., Shukri, N. H. A., Yusoff, H., Ramli, A., Zain, M. M., \& Bakar, N. A. A. (2017). Empowering social responsibility of Islamic organizations through Waqf. Research in International Business and Finance, 42, 959-965. https://doi.org/10.1016/ j.ribaf.2017.07.030.

Dewi, A. C., Fitriana, A., \& Setiawan, D. (2018). Perkembangan Penelitian di Bidang Pengungkapan di Indonesia: Telaah Konseptual (Research developments in the Field of Disclosure in Indonesia: Conceptual Study). Jurnal Siasat Bisnis, 22(1), 1-19. https:// doi.org/10.20885/jsb.vol22.iss1.art1.

Di Bella, V., \& Al-Fayoumi, N. (2016). Perception of Stakeholders on Corporate Social Responsibility of Islamic Banks in Jordan. EuroMed Journal of Business, 11(1), 30-56. https://doi.org/10.1108/EMJB-01-2015-0003.

El-Halaby, S., \& Hussainey, K. (2016). Determinants of Compliance with AAOIFI Standards by Islamic Banks. International Journal of Islamic and Middle Eastern Finance and Management, 9(1), 143-168. https://doi.org/10.1108/IMEFM-06-2015-0074.

Farook, S., Kabir Hassan, M., \& Lanis, R. (2011). Determinants of Corporate Social Responsibility Disclosure: The Case of Islamic Banks. Journal of Islamic Accounting and Business Research, 2(2), 114-141. https://doi.org/10.1108/17590811111170539.

Goby, V. P., \& Nickerson, C. (2016). Conceptualization of CSR among Muslim Consumers in Dubai: Evolving from Philanthropy to Ethical and Economic Orientations. Journal of Business Ethics, 136(1), 167-179. https://doi.org/10.1007/s10551- 014-2521-0.

Hassan, A., \& Latiff, H. S. B. A. (2009). Corporate Social Responsibility of Islamic Financial Institutions and Businesses: Optimizing Charity Value. Humanomics, 25(3), 177-188. https://doi.org/10.1108/08288660910986900.

Hassan, A., \& Harahap, S. S. (2010). Exploring Corporate Social Responsibility Disclosure: the Case of Islamic Banks. International Journal of Islamic and Middle Eastern Finance and Management, 3(3), 203-227. https://doi.org/10.1108/17538391011072417. 
Hesford, J. W., Lee, S.-H. S., Van der Stede, W. A., \& Young, S. M. (2006). Management Accounting: a Bibliographic Study. Handbooks of Management Accounting Research, 1, 3-26. https://doi.org/10.1016/S1751-3243(06)01001-7.

Ismaeel, M., \& Blaim, K. (2012). Toward Applied Islamic Business Ethics: Responsible Halal Business. Journal of Management Development, 31(10), 1090-1100. https://doi. org/10.1108/02621711211281889.

Jaiyeoba, H. B., Adewale, A. A., \& Quadry, M. O. (2018). Are Malaysian Islamic Banks' Corporate Social Responsibilities Effective? A stakeholders' View. International Journal of Bank Marketing, 36(1), 111-125. https://doi.org/10.1108/IJBM-10-2016- 0146

Kamla, R., \& G. Rammal, H. (2013). Social reporting by Islamic banks: Does Social Justice Matter? Accounting, Auditing \& Accountability Journal, 26(6), 911-945. https://doi. org/10.1108/AAAJ-03-2013-1268.

Khurshid, M. A., Al-Aali, A., Soliman, A. A., \& Amin, S. M. (2014). Developing an Islamic Corporate Social Responsibility Model (ICSR). Competitiveness Review, 24(4), 258274. https://doi.org/10.1108/CR-01-2013-0004.

Koku, P. S., \& Savas, S. (2014). On Corporate Social Responsibility and Islamic Marketing. Journal of Islamic Marketing, 5(1), 33-48. https://doi.org/10.1108/JIMA-04-2013- 0028.

Mallin, C., Farag, H., \& Ow-Yong, K. (2014). Corporate Social Responsibility and Financial Performance in Islamic Banks. Journal of Economic Behavior \& Organization, 103(Supplement), S21-S38. https://doi.org/10.1016/j.jebo.2014.03.001.

Migdad, A. M. (2017). CSR Practices of Palestinian Islamic Banks: Contribution to Socioeconomic Development. ISRA International Journal of Islamic Finance, 9(2), 133-147. https://doi.org/10.1108/IJIF-06-2017-0001.

Mostafa, R. B., \& ElSahn, F. (2016). Exploring the Mechanism of Consumer Responses to CSR Activities of Islamic Banks: the Mediating Role of Islamic Ethics Fit. International Journal of Bank Marketing, 34(6), 940-962. https://doi.org/10.1108/ IJBM-11-2015-0179.

Murphy, M. J., MacDonald, J. B., Antoine, G. E., \& Smolarski, J. M. (2019). Exploring Muslim Attitudes towards Corporate Social Responsibility: are Saudi Business Students Different? Journal of Business Ethics, 154(4), 1103-1118. https://doi.org/10.1007/ s10551-016-3383-4.

Neifar, S., \& Jarboui, A. (2018). Corporate Governance and Operational Risk Voluntary Disclosure: Evidence from Islamic Banks. Research in International Business and Finance, 46, 43-54. https://doi.org/10.1016/j.ribaf.2017.09.006.

Nobanee, H., \& Ellili, N. (2016). Corporate Sustainability Disclosure in Annual Reports: Evidence from UAE Banks: Islamic versus Conventional. Renewable and Sustainable Energy Reviews, 55, 1336-1341. https://doi.org/10.1016/j.rser.2015.07.084.

Platonova, E., Asutay, M., Dixon, R., \& Mohammad, S. (2018). The Impact of Corporate Social Responsibility Disclosure on Financial Performance: Evidence from the GCC Islamic Banking Sector. Journal of Business Ethics, 151(2), 451-471. https://doi. org/10.1007/s10551-016-3229-0. 
Rashid, M., Abdeljawad, I., Manisah Ngalim, S., \& Kabir Hassan, M. (2013). Customercentric Corporate Social Responsibility: A Framework for Islamic Banks on Ethical Efficiency. Management Research Review, 36(4), 359-378. https://doi. org/10.1108/01409171311314978.

Said, R., Abd Samad, K., Mohd Sidek, N. Z., Ilias, N. F., \& Omar, N. (2018). Corporate Social Responsibility Disclosure Index of Malaysian Shariah-Compliant Companies. International Journal of Ethics and Systems, 34(1), 55-69. https://doi.org/10.1108/ IJOES-09-2016-0068.

Sairally, B. S. (2013). Evaluating the Corporate Social Performance of Islamic Financial Institutions: an Empirical Study. International Journal of Islamic and Middle Eastern Finance and Management, 6(3), 238-260. https://doi.org/10.1108/IMEFM-02-2013- 0026.

Siwar, C., \& Hossain, T. (2009). An Analysis of Islamic CSR Concept and the Opinions of Malaysian Managers. Management of Environmental Quality: An International Journal, 20(3), 290-298. https://doi.org/10.1108/14777830910950685.

Sunarsih, U., \& Nurhikmah, N. (2017). Determinant of The Corporate Social Responsibility Disclosure. Etikonomi, 16(2), 161-172. https://doi.org/10.15408/etk.v16i2.5236.

Ullah, S., Jamali, D., \& Harwood, I. A. (2014). Socially Responsible Investment: Insights from Shari'a Departments in Islamic Financial Institutions. Business Ethics: A European Review, 23(2), 218-233. https://doi.org/10.1111/beer.12045.

Williams, G., \& Zinkin, J. (2010). Islam and CSR: A Study of the Compatibility between the Tenets of Islam and the UN Global Compact. Journal of Business Ethics, 91(4), 519-533. https://doi.org/10.1007/s10551-009-0097-x.

Wulandari, S. (2016). The Impact of Corporate Social Responsibility on Accrual Earnings Management and Real Earnings Management. Etikonomi, 15(1), 63-74. https://doi. org/10.15408/etk.v15i1.3116.

Yusof, M., Mohd Nor, L., \& Hoopes, J. E. (2014). Virtuous CSR: an Islamic Family Business in Malaysia. Journal of Family Business Management, 4(2), 133-148. https://doi. org/10.1108/JFBM-07-2013-0016.

Zafar, M. B., \& Sulaiman, A. A. (2019). Corporate Social Responsibility and Islamic Banks: a Systematic Literature Review. Management Review Quarterly, 69(2), 159-206. https:// doi.org/10.1007/s11301-018-150-x.

Zaki, A., Sholihin, M., \& Barokah, Z. (2014). The Association of Islamic Bank ethical identity and financial performance: evidence from Asia. Asian Journal of Business Ethics, 3(2), 97-110. https://doi.org/10.1007/s13520-014-0034-7.

Zaman, R., Roudaki, J., \& Nadeem, M. (2018). Religiosity and Corporate Social Responsibility Practices: Evidence from an Emerging Economy. Social Responsibility Journal, 14(2), 368-395. https://doi.org/10.1108/SRJ-10-2017-0204. 